\title{
Selection and characterization of a copper-resistant subpopulation of Schizosaccharomyces pombe
}

\author{
Stephen G. Whiteside and Donald J. Plocke* \\ Department of Biology, Boston College, Chestnut Hill, Massachusetts 02167, USA
}

(Received 31 January 1992; revised 29 May 1992; accepted 14 August 1992)

\begin{abstract}
Addition of $15 \mu \mathrm{M}-\mathrm{CuSO}_{4}$ to Schizosaccharomyces pombe 972 growing in a defined medium resulted in a biphasic growth curve and selection for a copper-resistant subpopulation. A clonal isolate of this subpopulation, designated strain SW40, had a decreased copper content per cell compared to the wild-type strain 972 . The copper-resistance trait was stable in the absence of selection, and was the result of a single recessive chromosomal mutation. Copper resistance was not the result of metal ion efflux, extracellular chelation or an increased oxidative stress response. The results are consistent with a copper-resistance mechanism in which a modification of the cytoplasmic membrane results in decreased copper accumulation.
\end{abstract}

\section{Introduction}

Copper is an essential element for the proper functioning of biological systems, but it is toxic when present in high concentrations (Lindegren et al., 1958; Martin, 1984; Ohsumi et al., 1988). Toxic effects include disruption of cytoplasmic membranes (Ohsumi et al., 1988), generation of free radicals (Babior, 1988), inhibition of certain enzymes (Moe et al., 1985) and inhibition of respiration (Lindegren et al., 1958; Nagai \& Nagai, 1958). In some cases, a number of apparently unrelated events may have a single underlying cause. For example, $\mathrm{Cu}^{2+}$ catalyse the formation of cytotoxic reduced oxygen species such as hydrogen peroxide and hydroxyl radicals (Babior, 1988). The latter are highly reactive molecules which inactivate enzymes and catalyse lipid peroxidations, resulting in the disruption of biological membranes (Babior, 1988; Bilinski et al., 1988).

In view of the toxicity of $\mathrm{Cu}^{2+}$, it is not surprising that specific mechanisms for resistance to these ions have evolved. Copper resistance mechanisms that have been identified or proposed are extracellular chelation (Murphy \& Levy, 1983), intracellular chelation (Hamer, 1986), increased oxidative stress responses (Naiki, 1980), energy-dependent efflux (Tynecka et al., 1981), and exclusion of $\mathrm{Cu}^{2+}$ (Foster, 1977; Rai et al., 1991). In the yeast Saccharomyces cerevisiae, copper resistance is usually the result of an increased production of metallothionein, which results in an increased intracellular

\footnotetext{
* Author for correspondence. Tel. (617) 552 3559; fax (617) 5522011 ;
} e-mail PLOCKE@BCVMS.BITNET. chelation capacity (Fogel et al., 1983). Exclusion of copper as a resistance mechanism has been proposed in several algae (Foster, 1977; Rai et al., 1991). Coppertolerant cells of Anabaena doliolum, for example, accumulate less copper than wild type cells (Rai et al., 1991). However, in this instance, copper tolerance is unstable in the absence of selection.

While there have been several studies involving copper uptake (Lin \& Kosman, 1990) and resistance (Fogel et al., 1983; Winge et al., 1985) in Sacch.cerevisiae, such information has not previously been reported with respect to Schizosaccharomyces pombe. We describe here the isolation and characterization of a copper-resistant strain of $S$. pombe. Resistance is the result of a single chromosomal locus (curl) and correlates with decreased copper accumulation by the resistant strains.

\section{Methods}

\footnotetext{
Organism. Schizosaccharomyces pombe strains (Table 1) 972 and 975 were obtained from the National Collection of Yeast Cultures (Norwich, UK). Strains FWP15, 165 and 172 were kindly provided by C. Hoffman (Boston College).

Growth media and conditions. Unless otherwise indicated, experiments were done with cells grown in EMM2 (Mitchinson, 1970). Adenine was added to a final concentration of $2 \mu \mathrm{g} \mathrm{ml}^{-1}$ where indicated. Bacto-agar $(2 \%, w / v)$ was added to EMM 2 and PM when solid media were used. PM was made up as described by Beach et al. (1985). YPG contains (w/v) 1\% yeast extract, $2 \%$ Bacto-peptone, $2 \%$ glucose and $2 \%$ Bacto-agar. MEA contains (w/v) 3\% malt extract and $2 \%$ Bacto-agar. All cultures were grown at $37^{\circ} \mathrm{C}$ without aeration unless otherwise indicated.
} 
Table 1. Description of $S$. pombe strains

\begin{tabular}{|c|c|c|c|}
\hline Strain & Genotype & Source & Construction method \\
\hline 972 & $h^{-}$, wild-type & \multirow{2}{*}{ NCYC } & - \\
\hline 975 & $h^{+}$, wild-type & & - \\
\hline FWP15 & $h^{-}$ade6-M216 & \multirow{4}{*}{ Charles Hoffman } & - \\
\hline FWP165 & $h^{+}$ade6-M216 leul-32 & & - \\
\hline & ura4-D18 & & - \\
\hline FWP172 & $\begin{array}{l}h^{-} \text {ade6-M210 leu } 1-32 \\
\text { ura } 4-D 18\end{array}$ & & - \\
\hline SW40 & $h^{-}$cur $1-151$ & \multirow{6}{*}{ This study } & $\begin{array}{l}\text { Exposure of } 972 \text { to } \\
15 \mu \mathrm{M}-\mathrm{CuSO}_{4}{ }^{*}\end{array}$ \\
\hline SW41 & $h^{+}$cur $1-151$ & & Tetrad dissection \\
\hline SW4 & $h^{-}$ade6-M216 & & Tetrad dissection \\
\hline SW5 & $h^{-}$ade6-M216 cur $1-151$ & & Tetrad dissection \\
\hline SW21 & $h^{+}$ade6-M210 & & Random spore \\
\hline SW30 & $h^{+}$ade6-M210 cur $1-151 \mathrm{~J}$ & & Random spore \\
\hline
\end{tabular}

*Strain SW40 was isolated as a single colony from a strain 972 culture selected for copper-resistant cells by exposure to $15 \mu \mathrm{M}-\mathrm{CuSO}_{4}$.

Growth and cell viability profiles. Mid-exponential phase $\left(\mathrm{OD}_{590} 0 \cdot 2-\right.$ $0 \cdot 5)$ overnight cultures of $S$. pombe were diluted to an $\mathrm{OD}_{590}$ of 0.1 and $\mathrm{CuSO}_{4}$ was added to the concentrations indicated in the figure legends. All copper concentrations were in addition to the $0.2 \mu \mathrm{M}-\mathrm{CuCl}_{2}$ present in EMM2. Growth curves were obtained from $\mathrm{OD}_{590}$ measurements in autoclaved $\mathrm{Kimax} 13 \times 100 \mathrm{~mm}$ screw-top tubes using a Spectronic 20 spectrophotometer. Anaerobic growth was measured using $13 \times 100 \mathrm{~mm}$ Pyrex test-tubes with fermentation locks. Stir bars were placed in the bottoms of the tubes to allow for mixing prior to $\mathrm{OD}_{590}$ measurements. Cell viability during growth was determined by diluting the culture with sterile deionized water at timed intervals, spreading aliquots on YPG plates and counting colonies after incubation for $3 \mathrm{~d}$. Strain SW40 was isolated as a single colony from a culture of strain 972 from which copper-resistant cells had been selected by exposure to $15 \mu \mathrm{M}-\mathrm{CuSO}_{4}$.

Copper uptake. Mid-exponential phase cultures $\left(\mathrm{OD}_{590} 0 \cdot 2-0 \cdot 5\right)$ were harvested by centrifugation $(8800 \mathrm{~g}$ for $10 \mathrm{~min})$ and washed twice with EMM2. Cells were resuspended to an $\mathrm{OD}_{590}$ of 0.1 in $\mathrm{EMM}_{2}-\mathrm{Cu}^{2+}$ (EMM2 made up without $\mathrm{CuCl}_{2}$ ). $\mathrm{Cu}^{2+}$ was then added as ${ }^{64} \mathrm{Cu}^{2+}$ to a final concentration of $0.2 \mu \mathrm{M}$ (approximately $1.5 \mathrm{MBq} \mathrm{ml}^{-1}$ ). $\mathrm{CuSO}_{4}$ was added to yield the concentrations indicated in Fig. 2 and Table 1. Samples $(100 \mu l)$ were removed at timed intervals and cells were harvested by suction filtration on nitrocellulose filters $(0.45 \mu \mathrm{m}$ pore size) followed by two $5 \mathrm{ml}$ washes with EMM2. The filters were then counted in a Beckman LS1800 scintillation counter using Aquasol as a scintillant. Total cell counts were estimated from a standard curve comparing cell number with $\mathrm{OD}_{590}$.

Removal of bound copper with EDTA. Strains 972 and SW40 were incubated with or without $15 \mu \mathrm{M}-\mathrm{CuSO}_{4}$ as described above. After incubation for $12.25 \mathrm{~h}$, samples $(100 \mu \mathrm{l})$ were harvested by suction filtration as above and washed once with $30 \mathrm{ml} 0.1 \mathrm{M}$-EDTA. Radioactivity on the filters was counted as described above.

Random spore analyses and strain construction. Random spore analyses and tetrad dissections were done as described by Gutz et al. (1974) and Hoffman \& Winston (1990). Colonies generated from the random spore analyses were screened for copper resistance by scoring for growth on EMM2 agar with $120 \mu \mathrm{M}-\mathrm{CuSO}_{4}$. The progeny of all crosses were screened for the desired phenotypes using selective media.

Construction and screening of diploid strains. Strains (Table 1) of opposite mating type containing the ade6-M210 and ade6-M216 alleles, which complement intragenically (Hoffman \& Winston, 1990), were mixed on MEA. After $1 \mathrm{~d}$, cells from the MEA were spread on PM agar and the resulting colonies replica-plated onto EMM2 with or without $120 \mu \mathrm{M}-\mathrm{CuSO}_{4}$. Diploid colonies were screened for copper resistance on EMM2 agar with $120 \mu \mathrm{M}_{-} \mathrm{CuSO}_{4}$. All incubations were done at $30^{\circ} \mathrm{C}$.

Cell extracts. All strains were streaked initially on EMM2 agar from liquid cultures grown in EMM2. After 2-3 d, cells were removed from the plates and inoculated in EMM2 at $37^{\circ} \mathrm{C}$. Mid-exponential phase cultures $\left(\mathrm{OD}_{590} 0 \cdot 2-0.5\right)$ were diluted to an $\mathrm{OD}_{590}$ of 0.1 and $\mathrm{CuSO}_{4}$ was added to the concentrations indicated in the figure legends. Anaerobic cultures were grown in flasks with fermentation locks. Cell cultures (approximately $200 \mathrm{ml}$ ) were grown to mid-exponential phase, harvested by centrifugation, and washed once with $10 \mathrm{ml} 10 \mathrm{~mm}$ $\mathrm{Na}_{2} \mathrm{HPO}_{4}$ containing 1 mM-EDTA (pH 7.8). All subsequent steps were done at $4{ }^{\circ} \mathrm{C}$. Cells were resuspended in $5 \mathrm{ml}$ of the phosphate buffer containing $0.1 \%$ Triton $\mathrm{X}-100$. An equal volume (about $5 \mathrm{ml}$ ) of glass beads $(450-500 \mu \mathrm{m}$ diam.) was added to the tube and the mixture was vortexed at high speed for $10 \mathrm{~min}$. The cell homogenate was centrifuged at $12000 \mathrm{~g}$ for $30 \mathrm{~min}$. The supernatant was stored at $-20^{\circ} \mathrm{C}$. The protein concentration of the supernatant was determined by the Lowry method using bovine serum albumin as a standard.

Enzyme assays. Catalase was assayed at $26^{\circ} \mathrm{C}$ according to the method of Aebi (1984). Superoxide dismutase was assayed at $37{ }^{\circ} \mathrm{C}$ according to the method of Spitz \& Oberley (1989).

Reductase assay. $\mathrm{Cu}^{2+}$ reductase activity was measured by a modification of the procedure of Dancis et al. (1990). Cultures were grown overnight in EMM2, cells $\left(\mathrm{OD}_{590} 0 \cdot 1-0.25\right)$ were harvested by centrifugation, washed once with $0.05 \mathrm{M}$-sodium citrate ( $\mathrm{pH} \mathrm{6.5)}$ containing $5 \%(\mathrm{w} / \mathrm{v})$ glucose and resuspended in the same. After $25 \mathrm{~min}, \mathrm{CuSO}_{4}$ and bathocuproine disulphonate were each added to $1.0 \mathrm{mM}$ at a final cell density of $10^{8}$ cells $\mathrm{ml}^{-1}$. Cells were harvested by centrifugation after $1 \mathrm{~h}$ and the $A_{485}$ of the supernatant was determined. The amount of $\mathrm{Cu}^{2+}$ reduced to $\mathrm{Cu}^{1+}$ was determined using a standard curve. The control consisted of reaction mixtures without cells. All incubations were done at $37^{\circ} \mathrm{C}$.

\section{Results and Discussion}

\section{Selection for a copper-resistant subpopulation}

The growth rate of $S$. pombe strain 972 exposed to $\mathrm{CuSO}_{4}$ concentrations in the 3-12 $\mu \mathrm{M}$ range (Fig. 1) decreased 


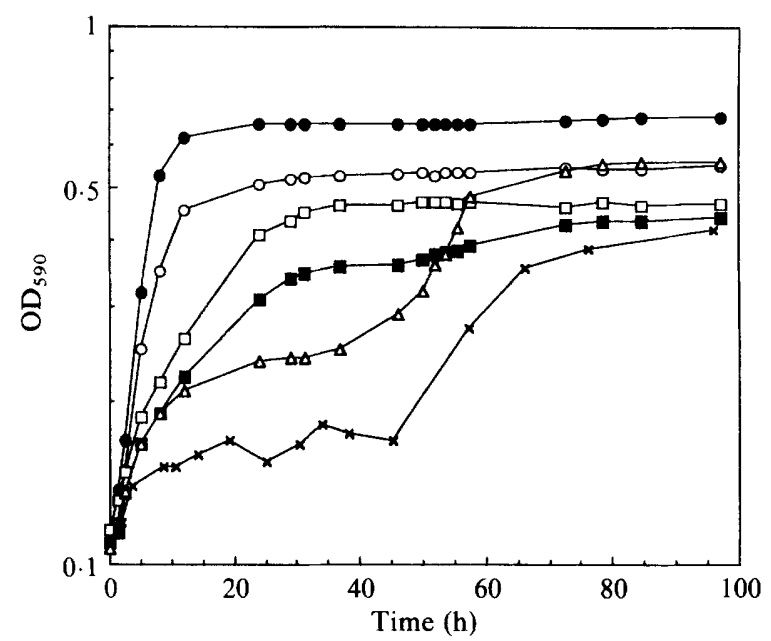

Fig. 1. Growth $\left(\mathrm{OD}_{590}\right)$ of $S$. pombe strain 972 with various $\mathrm{CuSO}_{4}$ concentrations under aerobic and anaerobic conditions. Aerobic cultures were grown with $0(\bigcirc), 3(\bigcirc), 9(\square), 12(\square)$ and $15(\triangle) \mu \mathrm{M}$ $\mathrm{CuSO}_{4}$; an anaerobic culture (X) was grown with $15 \mu \mathrm{m}-\mathrm{CuSO}_{4}$ Representative results are shown.

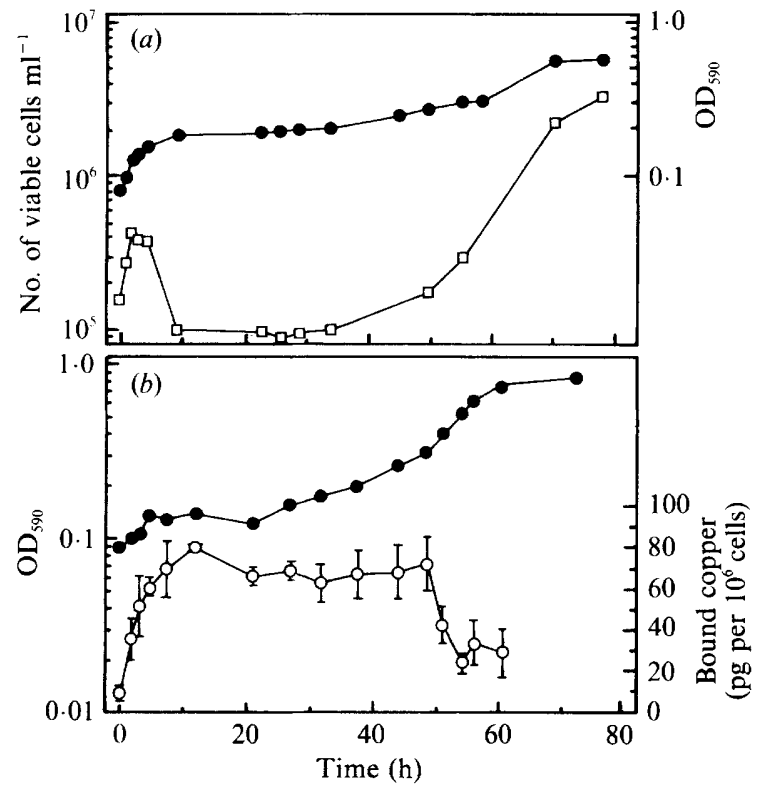

Fig. 2. Cell viability and amount of copper bound as a function of time for $S$. pombe strain 972 grown with $15 \mu \mathrm{M}-\mathrm{CuSO}_{4}(a) \square$, viable cells $\mathrm{ml}^{-1} ;(a)$ and $(b) \bigcirc, \mathrm{OD}_{590}$. (Representative results.) (b) $\mathrm{O}$, copper bound per $10^{6}$ cells. (The experiment was done three times; error bars represent one standard deviation).

with increasing $\mathrm{Cu}^{2+}$ concentration. At $\mathrm{CuSO}_{4}$ concentrations of $12,15 \mu \mathrm{M}$, biphasic growth profiles were observed. As seen in Fig. $2(a)$, on addition of $15 \mu \mathrm{M}-\mathrm{Cu}^{2+}$ an initial increase in the number of viable cells was followed by a precipitous drop after about $8 \mathrm{~h}$. At approximately $10 \mathrm{~h}$ the number of viable cells reached a minimum value while the amount of copper bound per cell was at a maximum. Following a lag period which varied in duration from one culture to another (see below), resumption of cell growth was observed as monitored by increases in viable cell counts and $\mathrm{OD}_{590}$ measurements (Fig. 2a), while the amount of copper bound per cell decreased during the same period (Fig. $2 b$ ). Plate assays indicated that in $1.45 \times 10^{4}$ $\left( \pm 0.4 \times 10^{4}\right)$ cells were viable when exposed to $15 \mu \mathrm{M}$ $\mathrm{CuSO}_{4}$ in EMM2. Under these conditions approximately $0.007 \%$ of the cells in populations of strain 972 were viable, indicating that selection for a copperresistant subpopulation occurred. Thus the biphasic growth observed with $15 \mu \mathrm{M}-\mathrm{Cu}^{2+}$ (Figs 1 and 2) based on $\mathrm{OD}_{590}$ measurements was not the result of an adaptation of cells in the culture to the presence of copper in the medium. These results also indicate that selection for copper-resistant cells results in a cell population which contains a lower copper content than the initial wild-type population (Fig. 2b). This conclusion is supported by the decreased copper content of strain SW40 as compared to strain 972 grown with $15 \mu \mathrm{M}-\mathrm{CuSO}_{4}$ (Table 2).

Biphasic growth profiles were also obtained for cultures derived from single colonies of strain 972 grown with $15 \mu \mathrm{M}-\mathrm{CuSO}_{4}$. However, variations in the duration of the lag phase (SD $=5.4 \mathrm{~h}, n=8)$ were noted in these experiments. Samples of cultures derived from one colony also showed the same variations, indicating that the selection for copper-resistant subpopulations is not simply the result of a heterogeneous cell population in the initial strain 972 culture. The fact that copper-resistant cells arise from cultures of clonal origin strongly suggests that any cell in populations of strain 972 has the potential for becoming copper-resistant.

\section{The copper-resistance trait: a genetic characterization}

Stability in the absence of selection is indicative of a genetic trait. Strain SW40 retained resistance to copper for a minimum of 85 generations in the absence of $15 \mu \mathrm{M}$ $\mathrm{CuSO}_{4}$. A stable genetic trait may be the result of chromosomal (Dancis et al., 1990), cytoplasmic (Smith et $a l ., 1990)$ or plasmid-based inheritance (Tynecka $e t$ al., 1981). A genetic trait based on a single chromosomal locus would be expected to segregate with a $1: 1$ frequency, in contrast to cytoplasmic or plasmid-based inheritance, neither of which would be expected to yield a 1:1 segregation frequency. Random spore analysis of a cross of strain SW40 with wild-type strain 975 resulted in an approximately $1: 1$ segregation of the copper-resistance trait (217 copper-resistant, 169 wild-type). The copper-resistance trait in strain SW40 is therefore the result of a modification at a single chromosomal locus. 
(a)

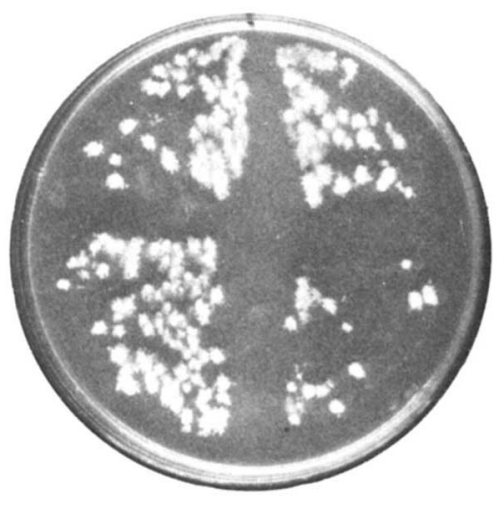

(b)

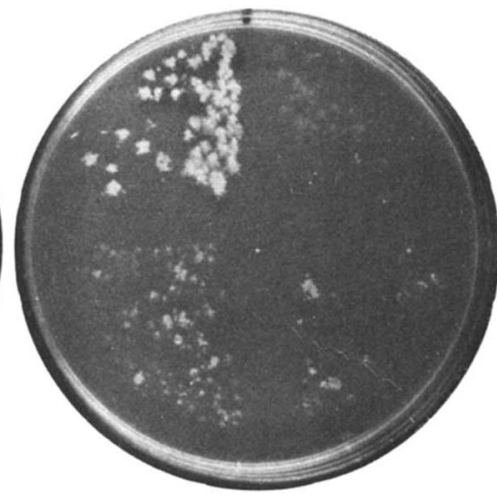

Fig. 3. Growth of diploid cells on EMM2 with $(b)$ and without (a) $120 \mu \mathrm{M}-\mathrm{CuSO}_{4}$. The plates were divided into quadrants, each of which contained diploid cells of varying genotypes: upper-left, SW $5 \times \mathrm{SW} 30$ $(\mathrm{CuR} \times \mathrm{CuR})$; upper-right, SW4 $\times$ SW21 (CuS $\times \mathrm{CuS})$; lower-right SW4 $\times$ SW30 $(\mathrm{CuS} \times \mathrm{CuR})$; lower-left, SW5 $\times \mathrm{SW} 21(\mathrm{CuR} \times \mathrm{CuS})$. The genotypes of the haploid cells strains are described in Table 1. (Representative results.)

Table 2. Binding of copper by cells before and after treatment with EDTA

All measurements were made after $12 \cdot 25$ h growth with or without $\mathrm{Cu}^{2+}$ as indicated. Results are means of three determinations, $\pm \mathrm{SD}$.

\begin{tabular}{|c|c|c|c|c|}
\hline \multirow[b]{2}{*}{ Strain } & \multirow[b]{2}{*}{$\begin{array}{c}\mathrm{CuSO}_{4} \\
\text { concn }(\mu \mathrm{M})\end{array}$} & \multicolumn{3}{|c|}{ Bound copper } \\
\hline & & $\begin{array}{l}\text { pg bound } \\
\text { per } 10^{6} \text { cells }\end{array}$ & $\begin{array}{c}\text { pg bound } \\
\text { per } 10^{6} \text { cells } \\
\text { after EDTA wash }\end{array}$ & $\begin{array}{c}\text { Percentage } \\
\text { removed } \\
\text { by EDTA }\end{array}$ \\
\hline 972 & 0 & $3.79 \pm 0.45$ & $3.36 \pm 0.012$ & $11 \cdot 3 \pm 0.31$ \\
\hline SW40 & 0 & $2.92 \pm 0.8$ & $2.55 \pm 0.105$ & $12.7 \pm 3.6$ \\
\hline 972 & 15 & $80 \cdot 0 \pm 1 \cdot 2$ & $45.7 \pm 4.5$ & $43.4 \pm 3.60$ \\
\hline SW 40 & 15 & $22.8 \pm 0.9$ & $10 \cdot 1 \pm 9.6$ & $20.5 \pm 2.19$ \\
\hline
\end{tabular}

Often, more than one locus is capable of conferring resistance to a toxic agent (Ono et al., 1988; Phelan et al., 1990). This possibility was examined using a series of independently selected copper-resistant strains. Eleven independently isolated $h^{+}$strains selected for resistance to $15 \mu \mathrm{M}-\mathrm{CuSO}_{4}$ were crossed with strain $\mathrm{SW} 40$. When the progeny of these crosses were screened for copper resistance, all were found to be copper-resistant. Thus, in each of these eleven cases, the copper-resistance trait resulted from an effect at the same genetic locus, which we have designated as cur1. The number of independently isolated copper-resistant strains examined did not constitute an exhaustive search for genes capable of conferring copper resistance in $S$. pombe. Nonetheless, these results show that cells with a genetic modification at a single chromosomal locus can be selected from wildtype populations by exposure to $15 \mu \mathrm{M}-\mathrm{CuSO}_{4}$. Also, this single locus is modified with high frequency [ 1 in $\left.1.45 \times 10^{4}\left( \pm 0.4 \times 10^{4}\right)\right]$ to generate copper-resistant cells.

Copper has been shown to act as a mutagen in mice (Agarwal et al., 1990). One possibility for the high frequency generation of copper-resistant cells is that copper also acts as a mutagen in $S$. pombe. To examine this hypothesis, several mutagenic assays were performed including the screening for mutations in the ade 6 and ade7 genes (Guglielminetti et al., 1967) of over 60000 colonies derived from cells exposed to copper. In no case was any mutagenic activity identified (data not shown), which makes it unlikely that copper is acting as a mutagenic agent in the generation of resistant cells.

A dominant/recessive test was used to examine expression of the copper-resistance trait in diploid cells (Fig. 3). The progeny of matings grown in the absence of copper served as a control. Resistance to $120 \mu \mathrm{M}-\mathrm{CuSO}_{4}$ was observed only in the copper-resistant homozygotes (Fig. 3), indicating that the trait is recessive in the diploid state.

\section{Enzyme activities and oxidative stress response}

In Sacch. cerevisiae a number of enzymes involved in response to oxidative stress, such as superoxide dismutase and catalase, increase in activity upon exposure to copper salts (Galiazzo et al., 1988), and a copperresistant strain of Saccho. cerevisiae has been isolated with increased superoxide dismutase activity as compared to wild-type strains (Naiki, 1980). Upstream 
Table 3. Superoxide dismutase, catalase and $\mathrm{Cu}^{2+}$ reductase activities of strains 972 and $S W 40$

Cells were grown aerobically or anaerobically, with or without $15 \mu \mathrm{M}-\mathrm{CuSO}_{4}$ as indicated.

Results are means of five determinations, \pm SD.

\begin{tabular}{|c|c|c|c|}
\hline \multirow[b]{2}{*}{ Strain } & $\begin{array}{l}\text { Superoxide } \\
\text { dismutase }\end{array}$ & Catalase & \multirow{2}{*}{$\begin{array}{l}\mathrm{Cu}^{2+} \text { reductase } \\
{\left[\text { nmol } \mathrm{Cu}^{2+}\right.} \\
\text { reduced per } 10^{8} \\
\left.\text { cells } \mathrm{h}^{-1}\right]\end{array}$} \\
\hline & \multicolumn{2}{|c|}{ [Units (mg protein) ${ }^{-1}$ ] } & \\
\hline \multicolumn{4}{|c|}{ (a) Aerobically grown } \\
\hline $972-\mathrm{Cu}^{2+}$ & $2.55 \pm 0.34$ & $4.68 \pm 0.31$ & $113 \cdot 2 \pm 12 \cdot 1$ \\
\hline $\mathrm{SW} 40+\mathrm{Cu}^{2+}$ & $2 \cdot 35 \pm 0.22$ & $9 \cdot 12 \pm 0.37$ & $61 \cdot 2 \pm 15 \cdot 0$ \\
\hline $\mathrm{SW} 40-\mathrm{Cu}^{2+}$ & ND & $8.42 \pm 0.60$ & $79.0 \pm 17.6$ \\
\hline $\mathrm{SW} 50+\mathrm{Cu}^{2+}$ & ND & $30.80 \pm 3.8$ & $\mathrm{ND}$ \\
\hline $\mathrm{SW} 50-\mathrm{Cu}^{2+}$ & ND & $20.6 \pm 3.02$ & ND \\
\hline \multicolumn{4}{|c|}{ (b) Anaerobically grown } \\
\hline $972-\mathrm{Cu}^{2+}$ & ND & $0.295 \pm 0.33$ & ND \\
\hline $\mathrm{SW} 40+\mathrm{Cu}^{2+}$ & ND & $15.44 \pm 1.72$ & ND \\
\hline $\mathrm{SW} 40-\mathrm{Cu}^{2+}$ & ND & $41.66 \pm 6.22$ & ND \\
\hline
\end{tabular}

activator sequences believed to be components of a copper-dependent transcriptional activation system have been identified for metallothionein and superoxide dismutase genes in Sacch. cerevisiae (Carri et al., 1991). In contrast, the superoxide dismutase activity of cell extracts from $S$. pombe strain $\mathrm{SW} 40$ grown in the presence of $\mathrm{CuSO}_{4}$ was not significantly different from that of the wild-type grown in the absence of copper (Table 3).

In contrast to the superoxide dismutase results, catalase activity was elevated in strain SW40, in a manner that was independent of the presence of copper in the growth medium (Table 3). Anaerobic growth conditions repressed catalase activity to undetectable levels in Sacch. cerevisiae, whether copper was present or not (Galiazzo et al., 1988). Comparable results were obtained with wild-type $S$. pombe grown anaerobically (Table 3). In strain SW40, however, catalase activity increased in cells grown anaerobically (Table 3 ). The inability of $\mathrm{Cu}^{2+}$ to catalyse the formation of reduced oxygen species under anaerobic conditions (reviewed in Bilinski et al., 1988) as well as the toxicity of $\mathrm{Cu}^{2+}$ under these conditions (Fig. 1) would seem to rule out a mechanism of copper resistance dependent on increased catalase activity.

\section{Intra- and extracellular chelation as potential resistance mechanisms}

Resistance to metal ions conferred by intracellular chelation (e.g. via metallothionein) normally results in metal ion accumulation (Hamer, 1986). Since strain SW40 accumulated less copper than the wild-type strain when grown with $15 \mu \mathrm{M}-\mathrm{CuSO}_{4}$ (Table 2), the copper resistance of strain SW40 is unlikely to be the result of intracellular chelation. In addition, although $S$. pombe produces class III metallothioneins (phytochelatins) when stressed with $\mathrm{Cu}^{2+}$ (Grill et al., 1986), these ions are poor inducers of phytochelatin synthesis in comparison to those of cadmium and nickel (Grill et al., 1986). Cell extracts from strain SW40 were assayed for the presence of phytochelatins using reverse phase HPLC according to the methods of Grill et al. (1986). Extracts from cultures grown with and without $\mathrm{CuSO}_{4}$ contained no detectable concentrations of phytochelatins (data not shown). This fact, along with the reduced copper content in the resistant cells, makes it unlikely that intracellular chelation by phytochelatins is a major contributor to copper resistance.

Resistance mechanisms resulting from decreased metal ion accumulation have been shown to result from energy-dependent efflux (Rouch et al., 1989), metal ion exclusion (Foster, 1977; Rai et al., 1991) or extracellular chelation (Murphy \& Levy, 1983). Energy-dependent efflux systems that confer resistance to a number of metal ions have been identified (Rouch et al., 1989; Tynecka et $a l ., 1981)$. These efflux systems are characterized by the exchange of labelled with unlabelled ions as observed by chase experiments (Tynecka et al., 1981). However, labelled $\mathrm{Cu}^{2+}$ could not be chased from either $S$. pombe strain 972 or SW40 (data not shown).

Extracellular chelation of $\mathrm{Cu}^{2+}$ should result in the immobilization and consequent detoxification of those ions by the copper-resistant cells. When copper-resistant cells were grown with $\mathrm{CuSO}_{4}$ in EMM2 to stationary phase, the $\mathrm{Cu}^{2+}$ in the resulting conditioned medium remained toxic to copper-sensitive cells (data not shown). Hence, extracellular chelation as a resistance mechanism does not appear likely. 


\section{$C u^{2+}$ reductase activities of strains 972 and $S W 40$}

Copper uptake by Debaryomyces hansenii (Wakatsuki et al., 1988) and Sacch. cerevisiae (D. Hamer, personal communication) depends on the reduction of $\mathrm{Cu}^{2+}$ to $\mathrm{Cu}^{1+}$. Alterations in $\mathrm{Cu}^{2+}$ reduction rates leading to decreased copper uptake might account for the decreased copper content of strain SW40 and the recessiveness of the curl allele. A comparison of $\mathrm{Cu}^{2+}$ reductase activity, using a whole cell assay, showed a decrease of approximately $30 \%$ in strain SW 40 as compared to 972 (Table 3). A decrease in reductase activity of this magnitude is probably not sufficient to account for the observed copper resistance for several reasons. First, in a comparable study of a copper-resistant strain of Sacch. cerevisiae there was no detectable cell-surface-associated $\mathrm{Cu}^{2+}$ reductase activity in the resistant strain (D. Hamer, personal communication). Second, it is unlikely that a $30 \%$ decrease in $\mathrm{Cu}^{2+}$ reductase activity would result in the large differences in copper accumulation between strains 972 and SW40 (Table 2).

The $\mathrm{Cu}^{2+}$ reductase activity of $S$. cerevisiae has been shown to decrease as a function of increasing $\mathrm{Cu}^{2+}$ concentration (Dancis et al., 1990; D. Hamer, personal communication). The reductase activity of strain SW40, however, is not significantly decreased by growth with $15 \mu \mathrm{M}-\mathrm{CuSO}_{4}$ (Table 3).

\section{Copper exclusion and resistance to membrane damage as potential resistance mechanisms}

Apart from the studies of De Vos et al. (1991), Foster (1977), and Rai et al. (1991) little information is available on the exclusion of copper as a resistance mechanism. One reason for this may be the difficulty in interpreting data on metal ion content of cells in which membrane damage has occurred.

The results in Table 2 are indicative of a resistance mechanism dependent on decreased accumulation of copper. This could be the result of protection from copper-induced membrane disruption (Ohsumi et al., 1988). Such a mechanism has been proposed for the higher plant Silene cucubalus (De Vos et al., 1991), for which it was demonstrated that the cytoplasmic membranes of copper-resistant populations were less susceptible to copper-induced ion leakage than copper-sensitive populations. In $S$. pombe, a mechanism of this sort could account for the difference in copper content of the wild type as compared to the resistant strain. $\mathrm{Cu}^{2+}$ bound to cells with damaged cytoplasmic membranes would probably be more accessible to EDTA than $\mathrm{Cu}^{2+}$ taken up by cells with intact membranes. Similar percentages (approximately $10 \%$ ) of bound $\mathrm{Cu}^{2+}$ were removed by EDTA from strain SW40 grown with or without added copper and strain 972 grown without added copper (Table 2). However, approximately $46 \%$ of the $\mathrm{Cu}^{2+}$ bound by strain 972 grown with added copper were accessible to EDTA. This suggests that cytoplasmic membrane disruption occurs when strain 972 , but not strain SW40, is exposed to $15 \mu \mathrm{M}-\mathrm{CuSO}_{4}$ (Table 2).

It has been proposed that $\mathrm{Cu}^{2+}$ damage cytoplasmic membranes via the catalysis of lipid peroxidations (De Vos et al., 1989). However, only fatty acids with at least two double bonds undergo peroxidation under physiological conditions (Bielski et al., 1983). Since Sacch. cerevisiae and $S$.pombe contain only saturated and monounsaturated fatty acids (Bilinski et al., 1989; Johnston \& Coddington, 1984), the membrane alterations observed with Sacch. cerevisiae and S. pombe would not seem to be the result of lipid peroxidation. This conclusion is supported by the observation that $\mathrm{Cu}^{2+}$ remain toxic to strain 972 under anaerobic growth conditions (Fig. 1), where the oxygen-requiring process of lipid peroxidation could not occur (Bielski et al., 1983).

The copper-resistance trait identified in this paper possibly involves modification of the cytoplasmic membrane resulting in decreased copper accumulation. This modification could confer copper resistance either by lowered activity of a copper transport system or increased stability of cytoplasmic membranes with respect to $\mathrm{Cu}^{2+}$. Either of these potential membrane modifications could result from decreases in the number or affinity of cell-surface copper-binding sites. The finding that copper resistance is attributable to a single genetic locus argues in favour of a single rather than a dual mechanism.

We thank C. Hoffman (Department of Biology, Boston College) for assistance with the genetics experiments and for helpful discussions.

\section{References}

AEBI, H. (1984). Catalase in vitro. Methods in Enzymology 54, 121-126. Agarwal, K., Sharma, A. \& Talukder, G. (1990). Clastogenic effects of copper sulfate on the bone marrow chromosomes of mice in vivo. Mutation Research 243, 1-6.

BABIOR, B. (1988). Microbial oxidant production by phagocytes. In Oxy-Radicals in Molecular Biology and Pathology, pp. 39-51. Edited by P. Cerutti, I. Fridovich \& J. McCord. New York: Alan R. Liss.

BeACH, D., Rodgers, L. \& Gould, J. (1985). Ran1 ${ }^{+}$controls the transition from mitotic division to meiosis in fission yeast. Current Genetics 10, 297-311.

Bielski, B., ARUdi, R. \& Sutherland, M. (1983). A study of the reactivity of $\mathrm{HO}_{2} / \mathrm{O}_{2}$-with unsaturated fatty acids. Journal of Biological Chemistry 258, 4759-4762.

Bilinski, T., Litwinska, J., Blaszczynski, M. \& BaJUs, A. (1989). Superoxide dismutase deficiency and the toxicity of the products of autooxidation of polyunsaturated fatty acids in yeast. Biochimica et Biophysica Acta 1001, 102-106.

Bilinski, T., KRaWiec, Z., LitwinsKa, J. \& BlaszczynsKi, M. (1988). Mechanism of oxygen toxicity as revealed by studies of yeast mutants with changed response to oxidative stress. In Oxy-Radicals in Molecular Biology and Pathology, pp. 109-123. Edited by P. Cerutti, I. Fridovich \& J. McCord. New York: Alan R. Liss. 
Carri, M., Galiazzo, F., Ciriolo, M. \& Rotilio, G. (1991). Evidence for co-regulation of $\mathrm{Cu}, \mathrm{Zn}$ superoxide dismutase and metallothionein gene expression in yeast through transcriptional control by copper via the ACE 1 factor. FEBS Letters 278, 263-266.

Dancis, A.. Klausner, R., Hinnebusch, A. \& Barriocanal, J. (1990). Genetic evidence that ferric reductase is required for iron uptake in Saccharomyces cerevisiae. Molecular and Cellular Biology 10, 2294-2301.

De Vos, C., Schat, H., De WaAl, M., Vooiss, R. \& ERnst, W. (1991). Increased resistance to copper-induced damage of the root cell plasmalemma in copper tolerant Silene cucubalus. Physiologia Plantarum 82, 523-528.

Fogel, S., Welch, J., Cathala, G. \& Karin, M. (1983). Gene amplification in yeast: CUPI copy number regulates copper resistance. Current Genetics 7, 347-355.

Foster, P. (1977). Copper exclusion as a mechanism of heavy metal tolerance in a green alga. Nature, London 269, 322-323.

Galiazzo, F., Schiesser, A. \& Rotilio, G. (1988). Oxy-independent induction of enzyme activities related to oxygen metabolism in yeast by copper. Biochimica et Biophysica Acta 965, 46-51.

Grill, E., WinNaCKer, E. \& ZeNK, M. (1986). Synthesis of seven different homologous phytochelatins in metal exposed Schizosaccharomyces pombe cells. FEBS Letters 197, 115-120.

Guglielminetti, R., Bonatti, S., Loprieno, N. \& ABbondadolo, A. (1967). Analysis of the mosaicism induced by hydroxylamine and nitrous acid in Schizosaccharomyces pombe. Mutation Research 4, 441-447.

Gutz, H., Heslot, H., Leupold, U. \& Loprieno, N. (1974). Schizosaccharomyces pombe. In Handbook of Genetics, pp. 395-446. Edited by R. King. New York: Plenum Press.

HAMER, D. (1986). Metallothionein. Annual Review of Biochemistry 55, 913-951.

HoFFMAN, C. \& WINSTON, F. (1990). Isolation and characterization of mutants constitutive for the expression of the $f b p l$ gene of Schizosaccharomyces pombe. Genetics 124, 807-816.

Johnston, P. \& CoDdington, A. (1984). Drug resistance in the fission yeast Schizosaccharomyces pombe: pleiotropic mutations affecting the oleic acid and sterol composition of cell membranes. Current Genetics 8, 37-43.

Lin, C. \& Kosman, D. (1990). Copper uptake in wild-type and copper metallothionein-deficient Saccharomyces cerevisiae: kinetics and mechanism. Journal of Biological Chemistry 265, 9194-9200.

LiNDEGREN, C., NAGAI, S. \& NAGAI, H. (1958). Induction of respiratory deficiency in yeast by magnesium, copper, cobalt, and nickel. Nature, London 182, 446-448.

MaRTIN, B. (1984). Bioinorganic chemistry of metal ion toxicity. In Metal Ions in Biological Systems, vol. 20, pp. 22-65. Edited by $\mathrm{H}$. Sigel. New York: Marcel Dekker.
Mitchinson, J. (1970). Physiological and cytological methods for Schizosaccharomyces pombe. Methods in Cell Biology 4, 131-165.

Moe, O., Pham, S., Selinsky, B. \& Dang, T. (1985). A kinetic study of the effects of $\mathrm{Co}^{2+}, \mathrm{Cd}^{2+}, \mathrm{Cu}^{2+}$, and $\mathrm{Ni}^{2+}$ on yeast inorganic pyrophosphatase. Biochimica et Biophysica Acta 827, 207-214.

MURPHY, R. \& LeVY, J. (1983). Production of copper oxalate by some copper tolerant fungi. Transactions of the British Mycological Society 81, $165-168$

NAGAI, S. \& NAGAI, H. (1958). Relation of the respiratory competence in yeast to color development and resistance to copper. Experimental Cell Research 15, 623-624.

NAIKI, N. (1980). Role of superoxide dismutase in a copper-resistant strain of yeast. Plant and Cellular Physiology 21, 775-783.

Ohsumi, Y., Kitamoto, K. \& ANRAKU, Y. (1988). Changes induced in the permeability barrier of the yeast plasma membrane by cupric ions. Journal of Bacteriology 170, 2676-2682.

Ono, B., Ohue, H. \& Ishihara, F. (1988). Role of the cell wall in Saccharomyces cerevisiae mutants resistant to $\mathrm{Hg}^{2+}$. Journal of Bacteriology 170, 5877-5882.

Phelan, A., Thurman, D. \& Tomsett, A. (1990). The isolation and characterization of copper-resistant mutants of Aspergillus nidulans. Current Microbiology 21, 255-260.

Rai, L., Mallick, N., Singh, J. \& Kumar, H. (1991). Physiological and biochemical characteristics of a copper tolerant and a wild type strain of Anabaena doliolum under copper stress. Journal of Plant Physiology 138, 68-74.

Rouch, D., LeE, B. \& CAMARKARIS, J. (1989). Genetic and molecular basis of copper resistance in Escherichia coli. In Metal Ion Homeostasis: Molecular Biology and Chemistry, pp. 439-446. Edited by D. Winge \& D. Hamer. New York: Alan R. Liss.

Smith, M., Duchesne, L., Bruhn, J. \& ANDERSon, J. (1990). Mitochondrial genetics in natural populations of the plant pathogen Armillaria. Genetics 126, 575-582.

SPITZ, D. \& ObERLEy, L. (1989). An assay for superoxide dismutase activity in mammalian tissue homogenates. Analytical Biochemistry 179, 8-18.

TYNECKA, Z., Gos, Z. \& ZAJAC, J. (1981). Energy-dependent efflux of cadmium coded by a plasmid resistance determinant in Staphylococcus aureus. Journal of Bacteriology 147, 313-319.

WaKatsuki, T., Iba, M. \& Imahara, H. (1988). Copper reduction by yeast cell wall material and its role in copper uptake in Debaryomyces hansenii. Journal of Fermentation Technology 66, 257-265.

Winge, D., Nielson, K., Gray, W. \& Hamer, D. (1985). Yeast metallothionein: sequence and metal binding properties. Journal of Biological Chemistry 260, 14464-14470. 